\title{
REVIEW
}

\section{Consequences of ecological connectivity: the coastal ecosystem mosaic}

\author{
Marcus Sheaves \\ School of Marine and Tropical Biology, James Cook University, Townsville, Queensland, Australia, 4811
}

\begin{abstract}
Connectivity links habitats in space and time. It is a key process that facilitates many life-history functions of myriad species in a variety of contexts over a wide range of scales. Perhaps its most obvious application is to the multifaceted linkages among the diverse habitat units comprising ecosystem complexes like the coastal ecosystem mosaic (CEM) - the tightly interlinked coastal, estuarine, wetland and freshwater habitats at the interface of land and sea. The ability to utilise this diversity of connected habitats is integral to the life histories of a broad spectrum of organisms, with connectivity between habitats being crucial to important functions like nursery utilisation. Although connectivity is an obvious feature of the CEM, investigation of its implications has largely been restricted to the migration of organisms. However, connectivity has much broader conceptual relevance. It is a pervasive and multifaceted process affecting and enabling the lives of organisms over the full range of conceptual scales, with ecosystem components connected by a diversity of factors, including physical and biological translocation of nutrients, ontogenetic, life history, spawning and feeding migrations, food-web dynamics, predator-prey interactions, and many more. All of these play crucial roles in structuring biological populations, communities and assemblages, and in driving the biological processes that support them. Moreover, connectivity is a prominent and necessary component of ecological concepts, ranging from estuarine dependence and metapopulation dynamics to foraging arena theory. Considering connectivity as a multifaceted process leads to specific hypotheses about the functioning of the CEM and similar ecosystem complexes.
\end{abstract}

KEY WORDS: Connectivity $\cdot$ Coastal ecosystems $\cdot$ Estuarine $\cdot$ Wetland $\cdot$ Ecosystem interactions Resale or republication not permitted without written consent of the publisher

\section{INTRODUCTION}

The term connectivity is widely applied throughout ecology. It is applied to a diversity of species, in a wide range of habitats, at a vast variety of scales and in many different contexts. Connectivity is crucial in regulating populations of organisms as diverse as watersnakes (Attum et al. 2007), gerbils (Blaum \& Wichmann 2007), bacterioplankton (Crump et al. 2007), diatoms (Vyverman et al. 2007), spiders (Baker 2007), reef fish (Dorenbosch et al. 2007) and brown bears (Graves et al. 2007). The concept has been applied in habitats from the artic (Crump et al. 2007) through temperate regions (Gelling et al. 2007) to the tropics (Sheaves 2005). Connectivity is apparent at scales from the centimetre-scale movement of rotifers to food patches (Ignoffo et al. 2005) to longdistance bird migration (Alerstam et al. 2007). From a conceptual point of view, connectivity is crucial in a broad spectrum of contexts from conservation (Jones et al. 2007) and pest and disease vector management (Grilli \& Bruno 2007) to gene flow (Boulet et al. 2007), the generation of species diversity (Genner et al. 2007), the regulation of competitive advantage (Hagen et al. 2007) and metapopultion dynamics (Hanski 1998).

In an ecological sense the concept of connectivity is most obviously, and most often, applied to the movements of animals, with connectivity playing an obvious and crucial role in the migrations of salmon (Schick \& Lindley 2007), butterflies (Rabasa et al. 2007) and birds (Alerstam et al. 2007). For instance, Secor \& Rooker 
(2005) discussed ideas of estuarine connectivity in a recent editorial, defining connectivity as '...the dependence of fish production and population dynamics on dispersal and migration among multiple habitats...' and linking connectivity to prominent concepts like estuarine dependence and metapopulation dynamics. In fact, connectivity has a variety of consequences that extend beyond the simple movement of the organisms themselves. Prominent among these is the central role connectivity plays in many trophic processes, including nutrient donations (Cloern 2007), nutrient cycling and availability (Meixner et al. 2007), and the translocation of nutrients by migrating animals (Jefferies \& Drent 2007). However, there has been much less focus on these other aspects and consequences of connectivity, although they have far-reaching consequences and conceptual relevance that impact almost all aspects of the lives of organisms. In fact, while publications and conferences about connectivity abound there has been little evaluation of the synergies and interactions among different aspects of connectivity or appraisal of the relative spatio-temporal importance of different connectivity factors.

The multifaceted roles and relevance of connectivity is exemplified in estuaries and the larger coastal ecosystem mosaic (CEM) that surrounds them. In a broad context, coastal ecosystems embrace the myriad freshwater, marine and wetland habitats situated between terrestrial environments and the deep ocean (Ray 2005). Their position at the interface of land and sea means they provide crucial links between terrestrial and offshore marine ecosystems (Irlandi \& Crawford 1997, Dittmar 1999, Davis et al. 2001a), facilitating a variety of functions from flood control (Chang et al. 2001) and pollution filtration (Scharler \& Baird 2005) to nutrient recycling (Alongi et al. 2000) and nursery ground utilisation (Robertson \& Duke 1987, Thayer et al. 1987).

Defining the units that comprise coastal ecosystems is difficult because they include habitats covering a diversity of spatial and conceptual scales. These units include estuaries, wetlands, streams, lakes, mangroves, seagrass, nearshore reefs, intertidal and subtidal benthic habitats, algal beds, and nearshore pelagic waters, among many others. Furthermore, although these units can be defined individually they are not mutually exclusive and the relationships between them are often ambiguous. For example, although mangroves are often major components of tropical estuaries, estuaries can exist without mangroves and mangroves occur on coral reef flats spatially separate from estuaries. Moreover, the importance of individual habitat components in coastal ecosystems can be out of proportion to their areal extent. For instance, connecting corridors comprise only small proportions of river drainages but, in providing links between habitats, contribute disproportionately to ecosystem function (Wissmar 2004, Sheaves
\& Johnston 2008). In fact, much of the diverse functionality of coastal ecosystems arises cumulatively from the interaction among ecosystem components (Amarasinghe 1997).

Such complexity is not confined to the CEM and even brief reflection suggests that many other ecosystems similarly comprise a diversity of units that interact in the lives of organisms, leading to similar levels of spatiotemporal complexity. Here I use the specific case of the CEM as a vehicle to explore the nature and consequences of the far-reaching and pervasive connectivity that affects almost all aspects of the lives of organisms. In doing so I use a broad ecological definition of connectivity that refers to physical or ecological events that allow materials or organisms to move between or influence habitats, populations or assemblages that are intermittently isolated in space or time.

\section{CONNECTIVITY}

At all ecological scales (evolutionary, community, population and individual) many, and perhaps even most, estuarine animals and plants are dependent on more than one habitat. Dependence on multiple habitats is obvious in the lack of concordance between the distributions of organisms and the scale and extent of identifiable habitats or ecosystem units. This can be seen, for instance, in the widespread occurrence among marine species of multipartite life cycles, featuring stage-specific occupation of distinct larval, juvenile and adult habitats (Meekan et al. 1993). Connectivity among units of the CEM goes far beyond this obvious linkage to manifest itself in a multitude of diverse ways and over a broad range of scales to produce a complex interlinking of habitats and functions.

\section{Movement and migration}

The most obvious manifestation of connectivity among units of the CEM is seen in the movements and migrations of animals, and dispersal of plant propogules. Movements such as the dispersal of mangrove or seagrass propagules link units of the same habitat type over a range of spatial scales (Drexler 2001), providing connections between patches that may be separated by considerable distances (De Lange \& De Lange 1994). Other movements and migrations link quite disparate habitat components, often as integral components of life-history strategies (Russell \& Garrett 1985, Barthem et al. 1991, Bagarinao 1994). This is exemplified in the central role of migration in supporting nursery ground function. This life-history connectivity is a pervasive force, with the population dynamics of many 
species and the productivity of many ecosystems dependent on migration and dispersal among multiple habitats (Secor \& Rooker 2005). The corollary of this is that these movements connect units of the CEM within the life histories of individuals and species.

Life-history connectivity is itself the sum of a series of smaller-scale connections: spawning migrations, dispersal and migration of eggs and larvae from spawning grounds, migrations into juvenile habitats (sometimes through a series of juvenile habitats), and migrations to join adult populations. These components display a variety of patterns and link habitats over many different scales. For example, the extensive migrations of eels link freshwater juvenile and adult habitats with distant marine spawning grounds (Arai et al. 2001), while the relatively local migrations of barramundi Lates calcarifer link estuaries and freshwater to nearshore spawning grounds (Davis 1986). Life-history migrations can even link areas at very different latitudes. Small numbers of the tropical carangid Caranx hippos regularly recruit to temperate waters north of Cape Hatteras on the east coast of the USA, an area well outside their normal range (McBride \& McKown 2000). Eventually these fish probably migrate back to re-enter tropical spawning populations (McBride \& McKown 2000), linking quite distant geographic areas.

A variety of smaller-scale movements, such as feeding migrations, tidal migrations, vertical migrations and migrations to refugia add to the complex connections between habitats created by life-history migration. The ecological relationships involved in these connectivities further enhance habitat linkages. For example, the migration of the snapper Lutjanus argentimaculatus to feed on sesarmid crabs in mangrove forests (Sheaves \& Molony 2000) forms a trophic link (transfer of nutrients and energy) between the mangrove forests and deeper water habitats that L. argentimaculatus must retreat to when the forest is exposed during low tide (Sheaves 2005). Similarly, the migration of predators to the mouths of estuaries to feed on recruiting fish larvae (Baker \& Sheaves 2005) links estuarine and coastal waters, both from a trophic perspective and from the perspective of the regulation of recruit availability in nursery habitats. In contrast, the migration of juvenile fish and crustacea into mangrove forests (Macia et al. 2003) and other shallow-water refuges (Crowder et al. 1997) moderates predator-induced mortality. At an even smaller scale, diel vertical migration of postlarval pink shrimp Farfantepenaeus duorarum enhances their advection through different areas of Florida Bay (Criales et al. 2005). Obviously many feeding, tidal and refuge related migrations are strongly interlinked, with the timing and extent of migration driven by the interplay of food availability and predation risk (Burrows 1994). Although these migrations may be distinct from life-history migrations, in many cases they are set within life-history migrations to form parts of a 'connectivityfractal' (Fig. 1) with a hierarchy of migrations at different scales connecting a diversity of habitats in complex ways and at a variety of scales.

At a larger conceptual scale, connectivity is a key component of metapopulation dynamics, providing the potential for recolonisation following extinction, which is the signature of a metapopulation structure (Hanski 1998). Metapopulation dynamics have been described for many coastal and estuarine systems (e.g. Ray 2005, Secor \& Rooker 2005), which demonstrate classic or source-sink metapopulation dynamics (Freckleton \& Watkinson 2002) depending on the scale and the details of the system being considered. In fact, species using subtropical estuarine wetlands may exhibit a mixture of source-sink and classic metapopulation dynamics depending on whether the focus is on freshwater or marine recruited components (Sheaves \& Johnston 2008). In the case of subtropical estuarine wetlands, connectivity can have an even more extensive role because it is the major factor determining key extinction factors like dry-down and salinity regime (Sheaves \& Johnston 2008).

\section{Connectivity and trophic function}

Even within a single habitat or ecosystem unit the concept of food webs implies connectivity. In marine systems food webs are complicated by ontogenetic omnivory (Polis \& Strong 1996), which is common in the CEM (Wilson \& Sheaves 2001), where nursery ground function is widespread. When the complexity necessitated by ontogenetic omnivory is added to that engendered by extensive connections between habitat units, it is clear that food webs must diversify and anastomose into complex multifaceted networks with a range of trophic consequences.

\section{Nutrient transport}

An obvious consequence of the movement of animals is the trophic linking of units of the CEM. Substantial volumes of nutrients move through the CEM by way of biologically mediated transport. At a basic level, biological nutrient transport may mirror simple physical processes. For example, the transport of nutrients in the form of aquatic organisms washed downstream into estuaries by freshwater flows (Kimmerer 2002) occurs in parallel with the downstream transport of nutrients by stream flow (Ford et al. 2005). In many other situations, more complex trophic interconnections resulting from feeding, spawning and life-history migrations can 


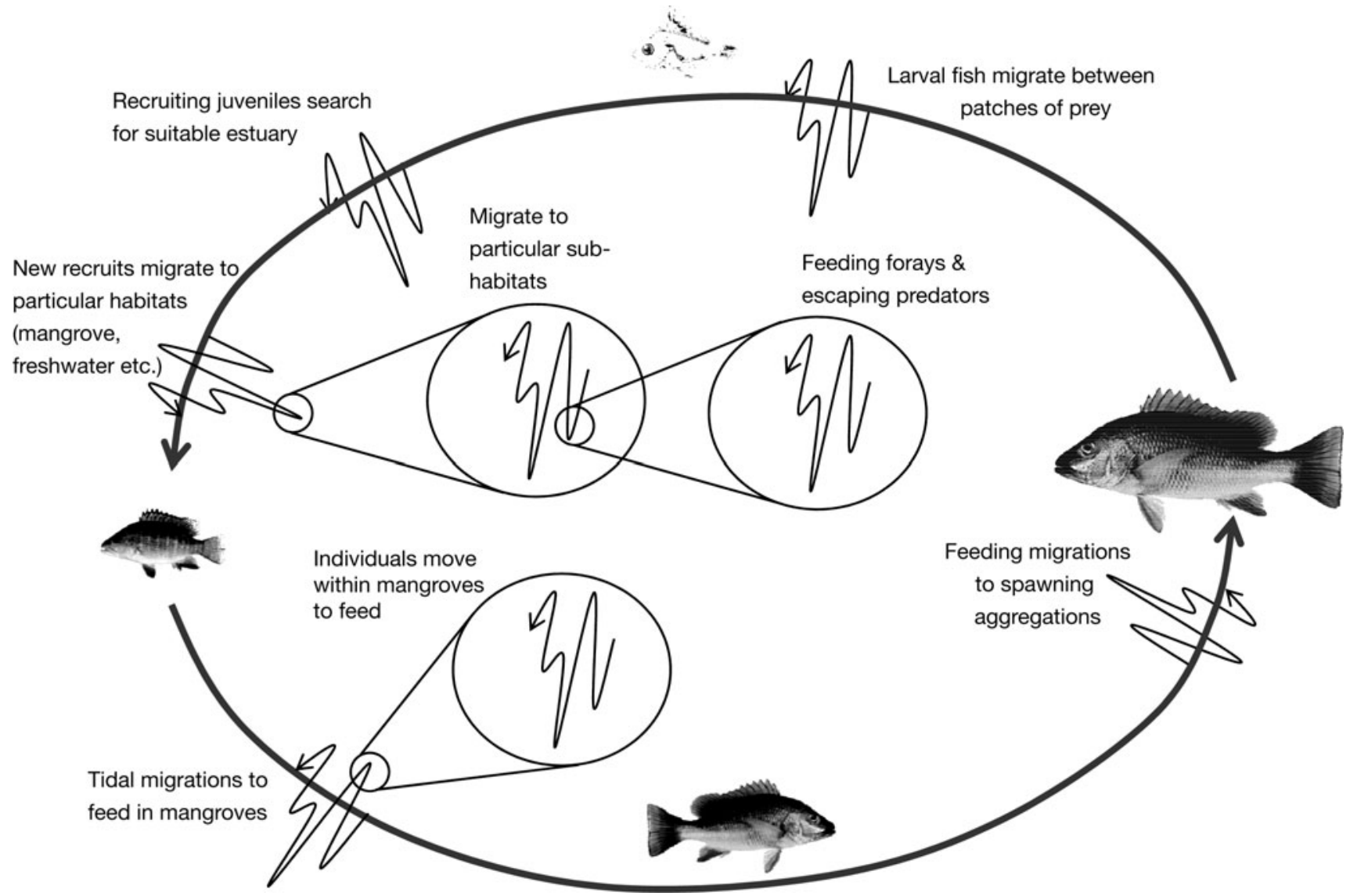

Fig. 1. Lutjanus argentimaculatus. Life-history migration of the mangrove jack, illustrating the hierarchy of migrations at a variety of scales that connect a variety of habitats in complex ways to produce a 'connectivity-fractal'

actively enhance and even redirect nutrient and energy flows. For instance, the movement of gulf menhaden Brevoortia patronus may result in an estimated export of some 5 to $10 \%$ of total primary production from estuaries in the Gulf of Mexico (Deegan 1993). In a similar vein, a considerable proportion of mangrove organic matter is made available for export in the form of eggs and larvae of brachyuran crabs (Schwamborn et al. 1999), a form more accessible to offshore consumers than would be the case for senescent mangrove litter (Lee 2008). Such biological transport of nutrients may be much more complex. When bluefish Pomatomus saltatrix and striped bass Morone saxatilis enter estuaries to feed (Buckel \& McKown 2002, Gartland et al. 2006) they transport energy and nutrients assimilated in coastal systems into the estuaries, but when they migrate offshore they transport energy and nutrients accumulated during estuarine residence back into coastal waters. Similarly, long-shore migrations of hundreds of $\mathrm{km}$, such as those common to a variety of fish on the central eastern Australian coast (Thomson 1955, Ward et al. 2003), can link trophic webs laterally across ecotones, latitudinal gradients and climatic regimes.
Nutrient sinks and recycling

Nutrients do not necessarily flow unimpeded through the CEM. Rather, connectivities are slowed down, as well as facilitated, by the actions of biological agents. For instance, although mangroves contribute considerable quantities of nutrients to other coastal ecosystems (Dittmar \& Lara 2001, Alongi et al. 1998), they also represent substantial nutrient sinks (Alongi 1996). Thus nutrient sinks are areas where the speed of movement of nutrients along connectivities is impeded. This inhibition is enhanced by a variety of recycling processes leading to nutrient retention. One specialised recycling pathway is seen in the retention of mangrove litter by the feeding of leaf-eating sesarmid crabs (Robertson \& Daniel 1989). The effectiveness of recycling by crabs is itself complicated by other connectivities. Crab-eating fish, such as mangrove jack Lutjanus argentimaculatus that enter mangrove forests at high tide to feed, translocate mangrove-derived nutrients when they return to subtidal habitats (Sheaves \& Molony 2000). Because these specialist crab eaters use estuaries as nursery grounds (Sheaves 1995) the complexity of the trophic 
connections is further complicated when they migrate to offshore adult habitats, mirroring the fractal-like complexity seen in life-history migrations (Fig. 1).

\section{Nutrient dynamics}

The use, reuse and cycling of nutrients in biological systems involves a diverse range of connectivities. These include small-scale, local interactions as well as exchanges with adjacent habitats and regions. Smallscale interactions include such things as carbon flows within local planktonic systems (e.g. Richardson et al. 2003) and wetland-water column nutrient exchanges in mangrove forests (Davis et al. 2001a). Larger-scale dynamics include ecotonal coupling (France 1995) and processes that support productivity at an ecosystem level, such as those illustrated in the various riverine production models (e.g. Junk et al. 1989, Sedell et al. 1989, Thorp \& Delong 1994). Nutrient exchanges at broader scales (e.g. adjacent habitats, ecosystems and regions; Rudnick et al. 2005) are often the product of a variety of smaller scale dynamics. For instance, local plankton dynamics drive regional variations in plankton productivity (Richardson et al. 2003) and combine with local and inter-regional seagrass nutrient dynamics (Fourqurean et al. 1997), the outflow of mangrove productivity (Davis et al. 2001b) and many other factors to support/drive complex nutrient fluxes in the Florida Bay-Everglades ecosystem complex (Ogden et al. 2005, Rudnick et al. 2005).

Nutrient subsidies are a feature of nutrient dynamics in an ecosystem mosaic and these are driven by, and imply, connectivity. Subsidies include nutrient export from freshwaters to estuaries (Chang et al. 2001), algae washed into mangroves from subtidal waters (Kristensen 2008), export of mangrove nutrients to subtidal areas by flushing (Alongi 1996) and tidally migrating fish (Sheaves \& Molony 2000), and the importance of seagrass and seagrass epiphytes to nutrition of fish in adjacent habitats (Connolly et al. 2005). Thus highly connected patches reliably receive 'donations' from other habitats, evening out fluctuations in productivity and potentially supporting more consumer biomass than would otherwise be the case (Jaramillo et al. 2006). Additionally, there is likely to be a high level of resource redundancy among components of the ecosystem complex, providing a potential stabilising influence on populations.

\section{Life-history connectivity and trophic function}

Fish life-history migrations are intimately linked to trophic function; both changes in habitat and changes in morphology require changes in diet. These concomitant changes mean ontogenetic omnivory is common (Wilson \& Sheaves 2001), resulting in complex food webs (Polis \& Strong 1996). Connectivity is often seen as having a particularly significant impact on recruitment success. For instance, larval fish entering estuarine nursery grounds aggregate at estuarine fronts (Kingsford \& Suthers 1994, 1996) where conditions favour the concentration of prey items (Bakun 2006) leading to enhanced likelihood of recruitment success. In fact, the importance of connectivity to larval survival is enshrined in well-known theories such as the membervagrant hypothesis (Sinclair 1988), where the survival of fish larvae is enhanced if they are transported to highly productive habitats, and the match-mismatch hypothesis (Cushing 1990), which links the survival of highly dispersive larvae to temporal connectivity with patches occupied by their prey. The fundamental characteristic of these models is that successful recruitment depends on connectivity between juvenile fish and their prey, and between spawning grounds and nursery patches. Thus increased connectivity between spawning, feeding and nursery patches increases recruitment success and ultimately increases the contribution of individual patches to productivity of the CEM as a whole (Gehrke $\&$ Sheaves 2006). Consequently, reliable connectivity should lead to less variable recruitment and promote metastable faunal compositions.

Consequences of connectivity among nutrient patches

Not only does connectivity play a central role in nutrient dynamics, transport and recycling, but it provides the opportunity, and often the necessity (e.g. during lifehistory migrations), for organisms to utilise multiple nutrient resource patches over space and time. This widespread and even obligatory use of a multiplicity of resource patches suggests that connectivity promotes assemblage metastability through the use of multiple patches and multiple carbon sources (Thorp et al. 2006). Additionally, connectivity probably enhances survival, growth, productivity and fitness by providing access to a diversity of resources not available if only one patch, habitat or ecosystem was available.

\section{Connectivity and predator-prey dynamics}

The diverse influences of connectivity on trophic function and life histories mean that connectivity is intricately intertwined with predator-prey dynamics. This is reflected in well-established theories like the foragingarena model (Walters \& Martell 2004), in which the ability of predators to reduce prey numbers is determined 
by the extent of prey access (i.e. connectivity) to refugia. Moreover, the connections between units of the CEM are often 'hot spots' where predation intensity peaks; hence, these connections are likely to be disproportionately important in population regulation and community structuring (Sheaves 2005). The importance of these areas of enhanced predation potential is encapsulated in the 'predator pit' hypothesis (Bakun 2006), where the relative concentration of predators and prey determine which benefits from utilising a hot spot. This understanding is pivotal because in the past the importance of spatial structuring of predation has received relatively little attention (Sheaves 2001), with most mathematical descriptions of predator-prey interactions failing to take spatio-temporal structure into account (DeAngelis \& Petersen 2001).

The risk of predation isn't spread evenly throughout habitats and ecosystems or over time (Sheaves 2001). Rather, predation events are focused at particular points in space and time, and are intimately linked with connectivity (Sheaves 2005). Small-scale predation hot spots often occur at interfaces such as between unvegetated substrates and seagrass (Peterson et al. 2001), and just outside the refuges provided by macrophyte and woody debris (Sass et al. 2006). Thus connections between habitats are often areas of high predation potential, so that the process of moving to utilise temporally available feeding or refuge habitats can represent a significant risk (Sheaves 2005).

At a broader scale, a variety of geological (Genin 2004) and oceanographic features (Bakun 2006) produce fronts that are areas of high productivity, retention areas for larvae, and areas of concentration of prey (Acha et al. 2004, Bakun 2006). Consequently, these areas are foci for intense predation events at a multiplicity of scales (Acha et al. 2004, Bakun 2006) involving animals as diverse as zooplankton (Genin 2004), larval fish (Bakun 2006), predatory fish (Zamon 2003), sea birds (Davoren et al. 2003, Weimerskirch et al. 2004), planktivorous sharks (Sims et al. 2003), and cetaceans (Atkins et al. 2004). These are areas that many members of the CEM occupy during feeding or life-history migrations, and are often integral links in connectivity between units of the CEM.

Clearly, connectivity is linked to predator-prey dynamics in myriad ways, being central to concepts such as foraging arena theory, hot spots and the tradeoff between the needs for food and refuge. When the link between connectivity and predator-prey dynamics is considered in the context of the diversity of species interacting throughout the CEM, it is clear that the interaction between connectivity and predation must be an important force in structuring assemblages and communities, and their patterns of change and stability over time and space.

\section{CONSEQUENCES OF CONNECTIVITY}

Although I have dealt with different aspects of connectivity separately they are obviously interlinked in many complex ways. Connectivity is obviously a multifaceted process, going far beyond simple movements of organisms among habitats. Indeed, connectivity prescribes that few, if any, habitats function independently in the lives of organisms. Organisms, populations, assemblages and communities all depend on a range of often disparate habitats and ecosystems, and link those habitat and ecosystem units into a complex mosaic. Moreover, the influence of connectivity can be seen at most biological scales (evolutionary, community, population and individual) and this influence varies over time and space. The widespread occurrence and diverse nature of connectivity makes it an omnipresent feature of the functioning of coastal ecosystems. Viewed in a broad context, connectivity is likely to be a pervasive process in many complex aggregations of ecosystems and habitats that parallel the CEM.

A broader conceptualisation of connectivity has a range of implications. Firstly, it implies the need to focus on the ecology of key connections rather than just on specific habitat units. This recognition is not new; the importance of edge effects is widely recognised (Connolly \& Hindell 2006), with effects often influenced by the nature of adjacent habitat types (Selgrath et al. 2007), emphasising the importance of interactions among habitats and the connections among them. Secondly, the multidimensional nature of connectivity emphasises that it is unlikely that most connectivity-related processes can be fully understood by considering only a single aspect of connectivity. Rather, outcomes are likely to flow from the conjunction of a suite of different facets of connectivity. Key questions then become (1) what is the overall impact of all the facets of connectivity on any particular outcome, (2) what are the synergies among different aspects of connectivity, and (3) what are the key components of connectivity driving particular processes? Beyond this, the complex nature of connectivity suggests that highly connected systems like the CEM are likely to exhibit emergent properties that may be crucial in determining the overall nature and metastability of ecosystems. All these issues translate into a suite of obvious and important research questions. Prominent among these are questions about the implications of dynamic and complex connectivity on the magnitude, and even the direction, of biotic transport of energy and nutrients between estuaries and coastal marine ecosystems (Deegan 1993), and the role of complex connectivity in supporting nursery ground function.

Although a detailed, holistic understanding is some way off, it is hard to ignore the importance of connectivity, and hard to see how detailed understanding of links 
between ecological processes and biological patterns can be achieved without considering the processes and patterns in a highly connected, ecosystem mosaic context. Unless connections among habitat units are recognised and understood in detail, the study of the organism-habitat interaction is likely to lead to a trivial or incomplete understanding. Although such complexity is difficult to study, its pervasive nature and the likelihood that it will throw up unexpected patterns means that it needs to be recognised, embraced and understood.

From an applied perspective, the maintenance of ecosystem linkages is critical to environmental health (Rudnick et al. 2005) and understanding connectivity is crucial in the context of the response of estuaries, their fauna and flora, and their management to both natural and human-induced change, from the most localised impacts to alterations in freshwater flows (Sheaves et al. 2007b) and global climate change (Sheaves et al. 2007a). For example, detailed understanding of connectivity is crucial in the context of adaptation to climate change. In the particular case of the CEM, facilitation of the progression of ecosystems (e.g. mangrove, salt marsh) across landscapes as sea levels rise will require specific knowledge of the myriad connectivities that interact to support habitat function and how these are likely to be impacted. This is particularly important because likely responses of humans to the threat of sea level rise, such as the imposition of dams, bunds and other barriers, are likely to directly impact connectivity. It is important that the management of such responses does not simply address the needs of the focal organisms (e.g. mangroves) to move but recognizes the complex linkages to other faunal components (e.g. the mangrove-eating crabs that influence mangrove health and resilience (Robertson 1991, Botto et al. 2005) and other connecting processes (e.g. nutrient dynamics). Similar arguments can be made for the management of environmental flows and invasive pest species. From a different perspective, connectivity between spawning and larval retention areas appears to be a key determinant of differences among tropical estuary fish assemblages (Sheaves \& Johnston unpubl. data). In turn, these connectivity-driven differences have substantial implications for the use of fish fauna as indices of health of tropical estuaries and the selection of estuaries as control sites for impact assessment.

Acknowledgements. I thank R. Johnston for his critical comments on this manuscript. The work in this paper complies with the current laws and ethics policies of Australia.

\section{LITERATURE CITED}

Acha EM, Mianzan HW, Guerrero RA, Favero M, Bava J (2004) Marine fronts at the continental shelves of austral
South America. J Mar Syst 44:83-105

Alerstam T, Baeckman J, Gudmundsson GA, Hedenstroem A and others (2007) A polar system of intercontinental bird migration. Proc R Soc Lond B Biol Sci 274:2523-2530

Alongi DM (1996) The dynamic of benthic nutrient pools and fluxes in tropical mangrove forests. J Mar Res 54:123-148

Alongi DM, Wattayakorn G, Ayukai T, Clough BF, Wolanski E, Brunskill GJ (2000) An organic carbon budget for mangrove-fringed Sawi Bay, southern Thailand. Spec Publ Phuket Mar Biol Cent 22:79-85

Alongi DM, Ayukai T, Brunskill GJ, Clough BF, Wolanski E (1998) Sources, sinks, and export of organic carbon through a tropical, semi-enclosed delta (Hinchinbrook Channel, Australia). Mangroves Salt Marshes 2:237-242

Amarasinghe MD (1997) Ecological functions of mangrove and related ecosystems and their contribution to economic sustainability. Sri Lanka J Aquat Sci 2:1-20

Arai T, Limbong D, Otake T, Tsukamoto K (2001) Recruitment mechanisms of tropical eels Anguilla spp. and implications for the evolution of oceanic migration in the genus Anguilla. Mar Ecol Prog Ser 216:253-264

Atkins S, Pillay N, Peddemors VM (2004) Spatial distribution of Indo-Pacific humpback dolphins (Sousa chinensis) at Richards Bay, South Africa: Environmental influences and behavioural patterns. Aquat Mamm 30:84-93

> Attum O, Lee YM, Roe JH, Kingsbury BA (2007) Uplandwetland linkages: relationship of upland and wetland characteristics with watersnake abundance. J Zool (Lond) 271:134-139

> Bagarinao T (1994) Systematics, distribution, genetics and life history of milkfish, Chanos chanos. Environ Biol Fishes 39: $23-41$

Baker L (2007) Effect of corridors on the movement behavior of the jumping spider Phidippus princeps (Araneae, Salticidae). Can J Zool 85:802-808

Baker R, Sheaves M (2005) Redefining the piscivore assemblage of shallow estuarine nursery habitats. Mar Ecol Prog Ser 291:197-213

> Bakun A (2006) Fronts and eddies as key structures in the habitat of marine fish larvae: opportunity, adaptive response and competitive advantage. Sci Mar 70(Suppl 2):105-122

Blaum N, Wichmann MC (2007) Short-term transformation of matrix into hospitable habitat facilitates gene flow and mitigates fragmentation. J Anim Ecol 76:1116-1127

Barthem RB, Brito Ribeiro M, Petrere M Jr (1991) Life strategies of some long-distance migratory catfish in relation to hydroelectric dams in the Amazon Basin. Biol Conserv 55:339-345

Botto F, Valiela I, Iribarne O, Martinetto P, Alberti J (2005) Impact of burrowing crabs on $\mathrm{C}$ and $\mathrm{N}$ sources, control, and transformations in sediments and food webs of SW Atlantic estuaries. Mar Ecol Prog Ser 293:155-164

> Boulet M, Couturier S, Cote SD, Otto RD, Bernatchez L (2007) Integrative use of spatial, genetic, and demographic analyses for investigating genetic connectivity between migratory, montane, and sedentary caribou herds. Mol Ecol 16:4223-4240

> Buckel JA, McKown KA (2002) Competition between juvenile striped bass and bluefish: resource partitioning and growth rate. Mar Ecol Prog Ser 234:191-204

> Burrows MT (1994) An optimal foraging and migration model for juvenile plaice. Evol Ecol 8:125-149

> Chang YH, Scrimshaw MD, Macleod CL, Lester JN (2001) Flood defence in the Blackwater estuary, Essex, UK: The impact of sedimentological and geochemical changes on salt marsh development in the Tollesbury Managed Realignment Site. Mar Pollut Bull 42:470-481

Cloern JE (2007) Habitat connectivity and ecosystem productivity: implications from a simple model. Am Nat 169:E21-E33 
Connolly RM, Hindell JS (2006) Review of nekton patterns and ecological processes in seagrass landscapes. Estuar Coast Shelf Sci 68:433-444

Connolly RM, Hindell JS, Gorman D (2005) Seagrass and epiphytic algae support nutrition of a fisheries species, Sillago schomburgkii, in adjacent intertidal habitats. Mar Ecol Prog Ser 286:69-79

Criales MM, Wang J, Browder JA, Robblee MB (2005) Tidal and seasonal effects on transport of pink shrimp postlarvae. Mar Ecol Prog Ser 286:231-238

Crowder LB, Squires DD, Rice JA (1997) Nonadditive effects of terrestrial and aquatic predators on juvenile estuarine fish. Ecology 78:1796-1804

Crump BC, Adams HE, Hobbie JE, Kling GW (2007) Biogeography of bacterioplankton in lakes and streams of an Arctic tundra catchment. Ecology 88:1365-1378

Cushing DH (1990) Plankton production and year-class strength in fish populations: an update of the match/mismatch hypothesis. Adv Mar Biol 26:249-293

Davis TLO (1986) Migration patterns in barramundi, Lates calcarifer (Bloch), in Van Diemen Gulf, Australia, with estimates of fishing mortality in specific areas. Fish Res 4:243-258

Davis SE III, Childers DL, Day JW Jr, Rudnick DT, Sklar FH (2001a) Wetland-water column exchanges of carbon, nitrogen, and phosphorus in a southern Everglades dwarf mangrove. Estuaries 24:610-622

Davis SE III, Childers DL, Day JW, Rudnick DT, Sklar FH (2001b) Nutrient dynamics in vegetated and unvegetated areas of a southern everglades mangrove creek. Estuar Coast Shelf Sci 52:753-768

Davoren GK, Montevecchi WA, Anderson JT (2003) The influence of fish behaviour on search strategies of common murres Uria aalge in the northwest Atlantic. Mar Ornithol 31:123-131

De Lange WP, De Lange PJ (1994) An appraisal of factors controlling the latitudinal distribution of mangrove (Avicennia marina var. resinifera) in New Zealand. J Coast Res 10: 539-548

> DeAngelis DL, Petersen JH (2001) Importance of the predator's ecological neighborhood in modeling predation on migrating prey. Oikos 94:315-325

Deegan LA (1993) Nutrient and energy transport between estuaries and coastal marine ecosystems by fish migration. Can J Fish Aquat Sci 50:74-79

Dittmar T (1999) Outwelling of organic matter and nutrients from a mangrove in North Brazil: Evidence from organic tracers and flux measurements. ZMT contribution 5, Center for Tropical Marine Ecology, Bremen, Dissertation, University of Bremen

> Dittmar T, Lara RJ (2001) Do mangroves rather than rivers provide nutrients to coastal environments south of the Amazon River? Evidence from long-term flux measurements. Mar Ecol Prog Ser 213:67-77

Dorenbosch M, Verberk W, Nagelkerken I, Van der Velde G (2007) Influence of habitat configuration on connectivity between fish assemblages of Caribbean seagrass beds, mangroves and coral reefs. Mar Ecol Prog Ser 334:103-116

Drexler JZ (2001) Maximum Longevities of Rhizophora apiculata and $R$. mucronata Propagules. Pac Sci 55:17-22

Ford P, Tillman P, Robson B, Webster IT (2005) Organic carbon deliveries and their flow related dynamics in the Fitzroy estuary. Mar Pollut Bull 51:119-127

$>$ Fourqurean JW, Moore TO, Fry B, Hollibaugh JT (1997) Spatial and temporal variation in C:N:P ratios delta super ${ }^{15} \mathrm{~N}$, and delta super ${ }^{13} \mathrm{C}$ of eelgrass Zostera marina as indicators of ecosystem processes, Tomales Bay, California, USA. Mar Ecol Prog Ser 157:147-157

France R (1995) Stable nitrogen isotopes in fish: Literature synthesis on the influence of ecotonal coupling. Estuar Coast Shelf Sci 41:737-742

Freckleton RP, Watkinson AR (2002) Large-scale spatial dynamics of plants: metapopulations, regional ensembles and patchy populations. J Ecol 90:419-434

Gartland J, Latour RJ, Halvorson AD, Austin HM (2006) Diet composition of young-of-the-year bluefish in the lower Chesapeake Bay and the coastal ocean of Virginia. Trans Am Fish Soc 135:371-378

Gehrke P, Sheaves MJ (2006) Research priorities to sustain coastal fisheries resources in the Great Barrier Reef region: A scoping study for the Tully-Murray catchment. CSIRO: Water for a Healthy Country National Research Flagship, Canberra

Gelling M, Macdonald DW, Mathews F (2007) Are hedgerows the route to increased farmland small mammal density? Use of hedgerows in British pastoral habitats. Landscape Ecol 22:1019-1032

Genin A (2004) Bio-physical coupling in the formation of zooplankton and fish aggregations over abrupt topographies. J Mar Syst 50:3-20

Genner MJ, Nichols P, Carvalho GR, Robinson RL, Shaw PW, Smith A, Turner GF (2007) Evolution of a cichlid fish in a Lake Malawi satellite lake. Proc R Soc Lond B Biol Sci 274: 2249-2257

Graves TA, Farley S, Goldstein MI, Servheen C (2007) Identification of functional corridors with movement characteristics of brown bears on the Kenai Peninsula, Alaska. Landscape Ecol 22:765-772

Grilli MP, Bruno M (2007) Regional abundance of a planthopper pest: the effect of host patch area and configuration. Entomol Exp Appl 122:133-143

> Hagen CA, Pitman JC, Robel RJ, Loughin TM, Applegate RD (2007) Niche partitioning by lesser prairie-chicken Tympanuchus pallidicinctus and ring-necked pheasant Phasianus colchicus in southwestern Kansas. Wildl Biol 13(Suppl 1):34-41

> Hanski I (1998) Metapopulation dynamics. Nature 396:41-49

Ignoffo TR, Bollens SM, Bochdansky AB (2005) The effects of thin layers on the vertical distribution of the rotifer, Brachionus plicatilis. J Exp Mar Biol Ecol 316:167-181

> Irlandi EA, Crawford MK (1997) Habitat linkages: The effect of intertidal saltmarshes and adjacent subtidal habitats on abundance, movement, and growth of an estuarine fish. Oecologia 110:222-230

Jaramillo E, De la Huz R, Duarte C, Contreras H (2006) Algal wrack deposits and macroinfaunal arthropods on sandy beaches of the Chilean coast. Rev Chil Hist Nat 79:337-351

Jefferies RL, Drent RH (2007) Arctic geese, migratory connectivity and agricultural change: calling the sorcerer's apprentice to order. Ardea 94:537-554

Jones GP, Srinivasan M, Almany GR (2007) Population connectivity and conservation of marine biodiversity. Oceanography (Wash DC) 20:100-111

Junk WJ, Bayley PB, Sparks RE (1989) The flood pulse concept in river-floodplain system. Can Spec Pub Fish Aquat Sci 106:110-127

Kimmerer WJ (2002) Physical, biological, and management responses to variable freshwater flow into the San Francisco estuary. Estuaries 25:1275-1290

> Kingsford MJ, Suthers IM (1994) Dynamic estuarine plumes and fronts: Importance to small fish and plankton in coastal waters of NSW, Australia. Cont Shelf Res 14:655-672

> Kingsford MJ, Suthers IM (1996) The influence of tidal phase on patterns of ichthyoplankton abundance in the vicinity of an estuarine front, Botany Bay, Australia. Estuar Coast Shelf Sci 43:33-54

Kristensen E (2008) Mangrove crabs as ecosystem engineers; with emphasis on sediment processes. J Sea Res 59:30-43 
Lee SY (2008) Mangrove macrobenthos: assemblages, services and linkages. Arch Fish Mar Res 59:16-29

Macia A, Abrantes KGS, Paula J (2003) Thorn fish Terapon jarbua (Forskaal) predation on juvenile white shrimp Penaeus indicus $\mathrm{H}$. Milne Edwards and brown shrimp Metapenaeus monoceros (Fabricius): the effect of turbidity, prey density, substrate type and pneumatophore density. J Exp Mar Biol Ecol 291:29-56

McBride RS, McKown KA (2000) Consequences of dispersal of subtropically spawned crevalle jacks, Caranx hippos, to temperate estuaries. Fish Bull 98:528-538

Meekan MG, Milicich MJ, Doherty PJ (1993) Larval production drives temporal patterns of larval supply and recruitment of a coral reef damselfish. Mar Ecol Prog Ser 93:217-225

Meixner T, Huth AK, Brooks PD, Conklin MH, Grimm NB, Bales RC, Haas PA, Petti JR (2007) Influence of shifting flow paths on nitrogen concentrations during monsoon floods, San Pedro River, Arizona. J Geophys Res 112: G03S03, DOI:10-D1029/2006JG000266

> Ogden JC, Davis SM, Barnes TK, Jacobs KJ, Gentile JH (2005) Total system conceptual ecological model. Wetlands 25: 955-979

Peterson BJ, Thompson KR, Cowan JH Jr, Heck KL Jr (2001) Comparison of predation pressure in temperate and subtropical seagrass habitats based on chronographic tethering. Mar Ecol Prog Ser 224:77-85

Polis GA, Strong DR (1996) Food web complexity and community dynamics. Am Nat 147:813-846

Rabasa SG, Gutierrez D, Escudero A (2007) Metapopulation structure and habitat quality in modelling dispersal in the butterfly Iolana iolas. Oikos 116:793-806

Ray GC (2005) Connectivities of estuarine fishes to the coastal realm. Estuar Coast Shelf Sci 64:18-32

Richardson TL, Jackson GA, Burd AB (2003) Planktonic food web dynamics in two contrasting regions of Florida Bay, US Bull Mar Sci 73:569-591

Robertson AI (1991) Plant-animal interactions and the structure and function of mangrove forest ecosystems. Aust J Ecol 16:433-443

Robertson AI, Daniel PA (1989) The influence of crabs on litter processing in high intertidal mangrove forests in tropical Australia. Oecologia 78:191-198

Robertson AI, Duke NC (1987) Mangroves as nursery sites: Comparisons of the abundance and species composition of fish and crustaceans in mangroves and other nearshore habitats in tropical Australia. Mar Biol 96:193-205

Rudnick DT, Ortner PB, Browder JA, Davis SM (2005) A conceptual ecological model of Florida Bay. Wetlands 25:870-883

Russell DJ, Garrett RN (1985) Early life history of barramundi, Lates calcarifer (Bloch), in north-eastern Queensland. Aust J Mar Freshw Res 36:191-201

Sass GG, Gille CM, Hinke JT, Kitchell JF (2006) Whole-lake influences of littoral structural complexity and prey body morphology on fish predator-prey interactions. Ecol Freshw Fish 15:301-308

Scharler UM, Baird D (2005) The filtering capacity of selected Eastern Cape estuaries, South Africa. Water SA 31:483-490

Schick RS, Lindley ST (2007) Directed connectivity among fish populations in a riverine network. J Appl Ecol 44:1116-1126

Schwamborn R, Ekau W, Silva AP, Silva TA, Saint-Paul U (1999) The contribution of estuarine decapod larvae to marine zooplankton communities in North-East Brazil. Arch Fish Mar Res 47:167-182

Secor H, Rooker JR (2005) Connectivity in the life histories of fishes that use estuaries. Estuar Coast Shelf Sci 64:1-3

Sedell JR, Richey JE, Swanson FJ (1989) The river continuum concept: A basis for the expected ecosystem behavior of very large rivers? Can Spec Pub Fish Aquat Sci 106: 49-55

Editorial responsibility: Antony Underwood,

Sydney, Australia
Selgrath JC, Hovel KA, Wahle RA (2007) Effects of habitat edges on American lobster abundance and survival. J Exp Mar Biol Ecol 353:253-264

Sheaves M (1995) Large lutjanid and serranid fishes in tropical estuaries: Are they adults or juveniles? Mar Ecol Prog Ser 129:31-40

Sheaves M (2001) Are there really few piscivorous fishes in shallow estuarine habitats? Mar Ecol Prog Ser 222: $279-290$

Sheaves M (2005) Nature and consequences of biological connectivity in mangrove systems. Mar Ecol Prog Ser 302: 293-305

Sheaves M, Molony B (2000) Short-circuit in the mangrove food chain. Mar Ecol Prog Ser 199:97-109

Sheaves M, Johnston RW (2008) Influence of marine and freshwater connectivity on the dynamics of subtropical estuarine wetland fish metapopulations. Mar Ecol Prog Ser 357:225-243

Sheaves M, Brodie J, Brooke B, Dale P and others (2007a) Vulnerability of coastal and estuarine habitats in the GBR to climate change. In: Johnson J, Marshal P (eds) Climate change and the Great Barrier Reef: a vulnerability assessment. GBRMPA, Townsville, p 593-620

> Sheaves M, Johnston R, Molony B, Shepard G (2007b) The effect of impoundments on the structure and function of fish fauna in a highly regulated dry tropics estuary. Estuaries 30: 507-517

Sims DW, Southall EJ, Richardson AJ, Reid PC, Metcalfe JD (2003) Seasonal movements and behaviour of basking sharks from archival tagging: No evidence of winter hibernation. Mar Ecol Prog Ser 248:187-196

Sinclair M (1988) Marine populations. An essay on population regulation and speciation. Washington Sea Grant, Seattle, WA

> Thayer GW, Colby DR, Hettler WF Jr (1987) Utilization of the red mangrove prop root habitat by fishes in South Florida. Mar Ecol Prog Ser 35:25-38

Thomson JM (1955) The movements and migrations of mullet (Mugil cephalus L.). Aust J Mar Freshw Res 6:328-347

Thorp JH, Delong MD (1994) The riverine productivity model: an heuristic view of carbon sources and organic processing in large river ecosystems. Oikos 70:305-308

Thorp JH, Thoms MC, Delong MD (2006) The riverine ecosystem synthesis: Biocomplexity in river networks across space and time. River Res Appl 22:123-147

Vyverman W, Verleyen E, Sabbe K, Vanhoutte K and others (2007) Historical processes constrain patterns in global diatom diversity. Ecology 88:1924-1931

Walters CJ, Martell SJD (2004) Fisheries ecology and management. Princeton Univesity Press, Princeton, NJ

Ward TM, Staunton-Smith J, Hoyle S, Halliday IA (2003) Spawning patterns of four species of predominantly temperate pelagic fishes in the sub-tropical waters of southern Queensland. Estuar Coast Shelf Sci 56:1125-1140

Weimerskirch H, Le Corre M, Jaquemet S, Potier M, Marsac F (2004) Foraging strategy of a top predator in tropical waters: Great frigatebirds in the Mozambique Channel. Mar Ecol Prog Ser 275:297-308

Wilson JP, Sheaves M (2001) Short-term temporal variations in taxonomic composition and trophic structure of a tropical estuarine fish assemblage. Mar Biol 139:787-796

Wissmar RC (2004) Riparian corridors of Eastern Oregon and Washington: Functions and sustainability along lowlandarid to mountain gradients. Aquat Sci 66:373-387

Zamon JE (2003) Mixed species aggregations feeding upon herring and sandlance schools in a nearshore archipelago depend on flooding tidal currents. Mar Ecol Prog Ser 261: $243-255$

Submitted: July 14, 2008; Accepted: May 20, 2009

Proofs received from author(s): September 18, 2009 